\title{
A TRIANONHOZ VEZETŐ ÚT. HISTORIOGRÁFIAI ÁTTEKINTÉS
}

\section{TOWARDS TRIANON. A HISTORIOGRAPHICAL SURVEY}

\author{
Romsics lgnác \\ az MTA rendes tagja, egyetemi tanár, Eszterházy Károly Egyetem, Eger \\ romsicsignac@t-online.hu
}

\section{ÖSSZEFOGLALÁS}

Az 1920-as trianoni békeszerződés értelmében Magyarország területe 325 ezer négyzetkilométerről (Horvátországot nem számítva 282 ezer négyzetkilométerről) 93 ezer négyzetkilométerre, lakosságának száma pedig 20,8, illetve 18,2 millióról 7,6 millióra csökkent. Az elcsatolt területeken élő 10,6 millió föből 3,3 millió, vagyis 30,2\% volt magyar. Ezekből a radikális változásokból következett, hogy a békeszerződés úgy a magyar historiográfiában, mint a magyar politikai gondolkodásban az elmúlt száz évben folyamatosan élénk viták tárgyát képezte. Tanulmányában a szerző ezeknek, a különböző történelmi korokra jellemző és egymással ellentétes ideológiai perspektívák által meghatározott értelmezéseknek a meghatározó jegyeit vizsgálja. Konklúziója szerint az 1980-as évek végére a magyar történészek többsége arra az álláspontra helyezkedett, hogy a történelmi Magyarország felbomlását alapvetően négy tényező okozta. Ezek a következők voltak: (1) az ország soknemzetiségű jellege és a különböző nacionalizmusok explozív ereje; (2) a szomszédos országok, különösen Szerbia és Románia irredenta politikája; (3) a Nagy Háború győztes nagyhatalmainak stratégiai érdekei; és (4) a Kárpát-medencében kialakult kaotikus háború utáni állapotok és a forradalmi kormányok inkompetenciája. Az 198990-es rendszerváltás óta a békeszerződés értelmezései fokozatosan diverzifikálódtak, melynek következtében a korábbi konszenzus egyre inkább felbomlani látszik.

\section{ABSTRACT}

The Treaty of Trianon, signed in 1920, reduced the area of Hungary from 329,000 square kilometers or, discounting Croatia, from 282,000 square kilometers to 93,000 square kilometers; while the country's population dropped from 20.8 million (or 18.2 million) to 7.9 million. Out of a total of 10.6 million people in the detached lands, 3.3 million or 30,2\% were ethnic Hungarians (Magyars). It followed from these radical changes that the peace treaty has remained a highly problematized and continuously discussed element in Hungarian historiography as well as in Hungarian political thinking throughout the last 100 years. In his essay the author analyses characteristic patterns of interpreting this transformation across eras, also contrasting various ideological perspectives. He concludes that by the 1980's the majority of Hungarian historians settled on four causes which they considered responsible for the break-up of historic Hungary. These were (1) the multiethnic character of the country and the explosive potential of the different nationalisms; (2) the irredentism of the neighboring countries, especially that of Serbia 
and Romania; (3) the strategic interests of the victorious great powers; and (4) the chaotic circumstances prevailing in the Carpathian basin after the war and the incompetence of the revolutionary governments. Since the change of régime in 1989-1990, explanations of the peace treaty have tended to become increasingly diverse once more, and the former consensus seems to have broken down.

Kulcsszavak: nemzetiségi kérdés, háborús hadicélok, irredentizmus, nagyhatalmi politika, békeszerződés, historiográfia

Keywords: nationality question, war aims, irredentism, policy of the great powers, peace treaty, historiography

A magánéleti tragédiát - legyen szó családi viszályról vagy egy balesetről - minden ember nehezen dolgozza fel. A nemzeti tragédiákkal ugyanígy vagyunk. Egyrészt nehéz megbarátkozni az új, a korábbinál előnytelenebb helyzettel, másrészt nem könnyű elkerülni a felelősségáthárító magyarázatok csapdáit. A magyar nemzet történetében az egyik legújabb ilyen nagy trauma az 1920-as trianoni békeszerződés. Nem elsősorban azért, mert ennek értelmében Magyarország elveszítette területének és nemzeti vagyonának mintegy kétharmadát. Hanem azért, mert az elcsatolt területeken több mint hárommillió magyar is élt. Ráadásul ezek mintegy harmada közvetlenül az új határok túloldalán, vagyis az új Magyarország magyarjaitól karnyújtási távolságra. Ez még azok számára is nehézzé, sőt gyakran lehetetlenné tette a döntésbe való tartós belenyugvást, akik egyébként elfogadták a multietnikus Magyarország nemzetiségeinek jogát a saját állam alapítására.

A nem várt és hatalmas sokk miatt évtizedekig burjánoztak a meseszerü és felelösségáthárító magyarázatok. Ezek egy része ma is él. Az évtizedek során a magyar történetírás ugyanakkor egy olyan racionális magyarázó sémát is kidolgozott, amelynek nemcsak Budapesten, hanem a világ bármely pontján hitele van. Írásunkban ennek kialakulását követjük nyomon, utalva az ettől eltérő véleményekre is.

$$
* * *
$$

Az 1918-19-es forradalmakat közvetlenül követő évek diskurzusát a hatalomra került konzervatív és jobboldali radikális erők reprezentánsainak értelmezései dominálták. Ezek közül Tormay Cécile naplóként prezentált visszaemlékezése (Bujdosó könyv), Bangha Béla politikai programadásának (Magyarország újjáépitése és a kereszténység) történeti bevezetője, valamint Szekfü Gyula nagy ívü történetpolitikai eszmefuttatása (Három nemzedék) gyakorolta a legnagyobb hatást. 
Ez a három 1920-as értelmezés jelentős mértékben különbözött. Tormay kizárólag az 1918-19-es forradalmárok, mindenekelőtt az „imbecillis pojácaként” ábrázolt Károlyi Mihály inkompetenciájával, Bangha és Szekfü pedig döntően a háború előtti évtizedek politikai fejleményeivel magyarázták az ország darabokra hullását. Eltért stílusuk is. Tormay szenvedélyesen gyülölködő és a személyesség illúzióját keltő narrációjához képest Bangha indulatosan, de személytelenül, Szekfü pedig higgadt és távolságtartó módon közölte érveit. A lényegben azonban egyezett véleményük: mindhárman belső okokkal indokolták a történteket, $\mathrm{s}$ e belső okok közül a bünbakká tett zsidóság és szövetségeseik, ,a szabadkőmüvesek, a szocialisták, a feministák és a galileisták” „destruktív” törekvéseinek tulajdonították a legnagyobb jelentőséget.

A két forradalom vezetői és hívei az 1920-as évek elején nem voltak abban a helyzetben, hogy a konzervatív és jobboldali radikális szerzők széles körökben népszerüsített „leleplezéseivel” hatékonyan szembeszállhattak volna. Külföldön megjelent, $\mathrm{s}$ az országba becsempészett emlékirataikban és politikai pamfletjeiben azonban módszeresen igyekeztek elhárítani magukról a Trianon miatt nekik tulajdonított felelősséget. Annál erőteljesebben hangoztatták a háború alatti és előtti „korhadt” és „reakciós” társadalmi-politikai rend, valamint a problémák adekvát kezelésére képtelen 1918 előtti kormánypolitika felelősségét. Károlyi Mihályt ugyanakkor olyan tragikus hősként láttatták, aki a reménytelen helyzetben mindössze kármentésre vállalkozhatott (Romsics, 2015, 331-337.).

Az 1920-as évek első felének jobb- és baloldali Trianon-diskurzusában tehát két olyan történelemkép körvonalazódott, amelyek tartalmilag diametrálisan szemben álltak egymással. Formai szempontból viszont nagyon is hasonlítottak, mondhatjuk: egymás tükörképei voltak. Hasonlóságuk abban állt, hogy mindkét megközelítés kizárólag belső okokra vezette vissza a történteket, s ezeket prezentálva előszeretettel élt a politikai ellenfelet bűnbakká stilizáló felelősségáthárítás mechanizmusaival. Azt a rosszat, amit az egyik fél szemében a „zsidók”, „szabadkőművesek” és Károlyi Mihály szimbolizáltak, a másikéban a „reakciós régi rend”, a „földbirtokos oligarchák” és Tisza István személyesítették meg. Egyedül Szekfü utalt rá, de ő is csak jelzésszerüen, hogy a trianoni döntés okai között a szomszédos államok irredentizmusa és a csehek államalapító törekvései is szerepet játszottak. A tágabb értelemben vett külpolitikai dimenzió, vagyis a győztes nagyhatalmak érdekvezérelt politikája azonban nemcsak szerzőtársai, hanem az ő szempontjai közül is hiányzott. Ezt a nyilvánvaló fogyatékosságot igyekezett pótolni Horváth Jenő diplomáciatörténész, egyetemi magántanár, aki elsőként vállalkozott a döntés nemzetközi meghatározottságának vizsgálatára.

1924-től megjelenő különböző munkáiban Horváth részletesen foglalkozott a délszlávok és a románok háború előtti és alatti nemzetegyesítő törekvéseivel, valamint a fiatalabb cseh politikusok szeparatizmusával, mindenekelőtt Tomáš Garrigue Masaryk és Edvard Beneš háború alatti aktivitásával. Megállapította, hogy 
ezek a törekvések „Ausztria-Magyarország felosztását célozták”, és ennyiben az 1919-20-as békeszerződések irányába mutattak. Hasonló súllyal estek latba a háborús győzelem elérése érdekében Szerbiának, Olaszországnak és Romániának tett 1914-es, 1915-ös és 1916-os területi ígéretek, amelyek elörevetítették a központi hatalmak veresége esetén várható hatalmas magyar területi veszteségeket. S mindehhez járultak a győztes antanthatalmak távlatos stratégiai céljai, mindenekelőtt Németország sakkban tartása érdekében ,a németek hátában álló szlávok támogatása", valamint az osztrákok és a magyarok gyengítése (Horváth, 1924, 3-34.).

1929-ben Chicagóban és angolul (The Dissolution of the Habsburg Monarchy) megjelent monográfiájában Jászi Oszkár három tényezőre vezette vissza a Habsburg Birodalom és ezen belül a történelmi Magyarország felbomlását. Ezek a következők voltak: (1) a nemzetiségek öntudatra ébredése, akiknek a vezetői egyre világosabban látták, hogy önállósulási céljaik elérése a Habsburg Birodalmon belül „hiú remény”, s megoldást csak a kiválás hozhat; (2) a környező országok irredentizmusa, amelyet a háború során az antanthatalmak is felkaroltak; és (3) a világháború, amely katalizátori hatást gyakorolt a nemzetileg motivált belső ellentétekre, s ezzel „kulminációjává” vált „,egy belső dezintegrálódási folyamatnak". A történeti magyar állam felbomlását Jászi tehát egy olyan hosszan tartó „belső fejlődés” eredményének tartotta, amelyet a „külső, háborús komplikációk" legfeljebb csak siettettek és elősegítettek, és amely alapvetően illeszkedett az államfejlődés általános európai modelljéhez: a közös nyelvet beszélő és közös kultúrában élő népek nemzetileg homogén vagy homogénebb és független politikai közösségekké szerveződéséhez. A nemzeti államok kialakulását mindazonáltal nem elkerülhetetlen szükségszerüségként, hanem a történelmi lehetőségek egyikeként fogta fel. Ha a „Monarchia összes nemzetei - tért vissza régi, kedves ideájához - önkormányzatot nyertek volna, és a birodalom fokozatosan a népek szabad konföderációjává alakult volna", úgy számos irredentát le lehetett volna csendesíteni a határokon belül (Jászi, 1982, 75., 478-479., 557.).

A nemzetállami átalakulás feltartóztathatatlanságának s ennyiben Trianon elkerülhetetlenségének tézisét részletesebb formában a német népiségtörténet szempontjait adaptáló magyar történetírók és politikai gondolkodók fejtették ki az 1930-as években. Ennek egyik első szószólója Asztalos Miklós, Erdélyből menekült könyvtáros és nemzetiségpolitikai szakértő, az 1925-ben alakult Bartha Miklós Társaság egyik elnöke volt. A magyarországi nemzetiségi kérdés történetét ismertető 1934-es kismonográfiájában Asztalos feltételezte, hogy semmiféle nemzetiségi politika „sem lett volna alkalmas arra, hogy a bekövetkezendőket feltartóztassa”. „A nemzetiségek már tisztában voltak céljukkal, mely mindenütt az volt, hogy az általuk lakott területen a saját nemzeti nyelvük érvényesüljön, s hogy teljes tömegükben politikai jogokat nyerjenek.” A felbomlás tehát nem politikai hibák, hanem a nemzetiségi lakosság politikai törekvéseinek hosszabb 
távon elkerülhetetlen következménye volt. Az egyetlen dolog, amit a magyar kormánypolitikának tennie lehetett és kellett volna - hangsúlyozta Asztalos -, a magyarság megerősítése, vagyis egy olyan preventív nemzetvédelmi politika lett volna, amely telepítéssel és célzott állami támogatásokkal „megvédte volna a veszélyeztetett területek magyarságát" (Asztalos, 1934, 41., 86-87.). Asztalossal egyidejűleg a polihisztor Németh László is hangot adott hasonló véleményének. Szekfü Gyulával vitatkozva egyik 1934-es írásában evidenciaként fogalmazta meg, hogy „A Habsburg-monarchiát a nacionalizmus végső következése, a népek önrendelkezésének az elve dobta szét; mihelyt nemzetiségeinket ez a XIX. századi elv teljesen hatalmába kerítette, Magyarország régi alakjában nem maradhatott fenn, az engedékenység éppúgy felrobbantotta volna, mint a türelmetlenség”. (Németh, 1989, 119.)

Asztalossal és Németh Lászlóval egyezően értelmezte Trianon okait Szabó István levéltáros, 1943-tól a debreceni egyetem történészprofesszora is, 1941-es népiségtörténeti összefoglalásában. „A magyarországi nemzetiségek nacionalizmusa is, mint minden nacionalizmus - írta -, saját politikai életforma kiküzdésére törekedett.” 1848-49-ben ugyan még csak autonómiát követeltek, ám „minden igény mögött végső célként, kimondva vagy kimondatlanul, a teljes politikai hatalom kézbevétele rejlett: a nemzetiség állami önállósága, illetőleg a nemzetiségnek az anyanép államába való térése, egyben tehát a magyar állam felbontása.” Az asszimiláció, amelyben a magyar vezető réteg reménykedett, és amelyre iskolapolitikájával törekedett, a kor magyarságának „,nagy tévedése” volt. Bár a városi lakosság, a szórványok és a nyelvhatárok közelében élők körében markáns jelei mutatkoztak a magyarosodásnak, ,a magyarság és a nemzetiségi tömbök népterületeinek érintkezési vonala az 1790-es évek óta lényegében nem mozdult". Az összefüggő, tömör nemzetiségi területek lakossága nem magyarosodott. Magyarország tehát „e tekintetben eleve valószínütlen és megoldhatatlan feladat előtt állt" (Szabó, 1941, 204-230.).

A második világháború utáni radikálisan új politikai helyzetet bevezető néhány éves átmeneti periódusban ketten érintették a témát: Bibó István és Andics Erzsébet. A népi mozgalomhoz kötődő és elkötelezetten demokrata Bibó a népiségtörténeti megközelítésnek megfelelően a kelet- és közép-európai nacionalizmusok magától értetődő törekvésének tartotta a saját államiság utáni vágyakozást (Bibó, 1981, 207-213.). A felbomlást elkerülni - feltételezte Jászi Oszkárhoz hasonlóan csak egy nagyon radikális és a nemzetiségeket egyenjogúsító demokratikus átalakulással lehetett volna - talán. Egy ilyen átalakulás azért lett volna kétesélyes, mert - mutatott rá - „ugyanúgy jelenthette az asszimiláció lehetőségét, mint az elszakadás veszélyének a felidézését” (Bibó, 1981, 269-270.).

A Moszkvából hazatért Andics Erzsébet részben a marxizmus internacionalizmusát és osztályszempontjait, részben a nemzetek önrendelkezési jogát hangoztató leninizmus dogmáját alkalmazta a magyarországi helyzetre. A nemzetiségek 
önállósodási törekvéseit ennek megfelelően ,jogosnak”, a független nemzetállamok kialakulását pedig a „történelmi fejlődés hatalmas eredményének” és „minden további haladás előfeltételének” minősítette. „[M]inden nemzetnek, kicsinek, nagynak - hangoztatta Karl Marxra és Friedrich Engelsre hivatkozva - egyaránt szuverén joga belső ügyeit a saját tetszése szerint önállóan intézni. Egyetlen nemzetnek sincs joga más nemzetek ügyébe beavatkozni, azok függetlenségét korlátozni, szabadságát megnyirbálni.” „A nemzetiségi kérdés egyetlen gyökeres megoldása a népek önrendelkezési jogának teljes elismerése.” A magyar vezető körök 19. századi törekvése magyarok és nem magyarok ,eröszakos összetartására a magyar szentistváni állam keretei között” éppen ezért ,igazságtalan, reakciós, imperialista politika” volt. Ugyanis ,nemcsak az imperializmus, ha más népek meghódítására törekszünk, hanem az is, ha idegen népeket erőszakkal igyekszünk uralmunk alatt tartani” (Andics, 1949, 5., 14-15.).

Az 1948-49-es kommunista hatalomátvételt követő évek hivatalos történelemszemléletét természetesen nem az 1949-ben félreállított Bibó, s nem is a debreceni egyetemen elszigetelődött Szabó István, hanem Andics Erzsébet nézetei határozták meg. Ezzel magyarázható, hogy a magyar történelmi elitet egyedüli felelősként, sőt osztályérdekei által vezérelt önző hazaárulóként prezentáló hamis interpretációjának megállapításai a hazai történeti irodalomnak és a politikai publicisztikának ugyanolyan toposzaivá váltak, mint Tormay Cécile-é, Bangha Béláé, Szekfü Gyuláé és követőiké a Horthy-korszakban.

A kádári liberalizmus körülményei között újra szakszerűsödő magyar történetírás az 1960-as évek közepétől kezdett szakítani ezzel a politikailag durván meghatározott propagandisztikus szemlélettel. A párizsi békekonferencia és Magyarország 1918-19-es kapcsolatrendszerét vizsgáló 1965-ös szakmonográfiájában L. Nagy Zsuzsa tényszerüen ismertette a trianoni döntés irányába mutató háború alatti titkos szerződéseket, amelyekre hivatkozva az ország elszakadásra törekvő nem magyar népei sikerrel teremtettek kész helyzeteket - függetlenül a békekonferencia döntéseitől. Nem tagadta, hogy a „pacifista” és „,antantbarát” Károlyi-kormány „nem tudott $\mathrm{s}$ nem is mert hatékonyan fellépni a nemzetiségek ellen". Döntő tényezőnek azonban nem ezt, hanem a nagyhatalmi érdekeket és politikát tartotta (L. Nagy, 1965, 8., 24-25., 230.).

Hanák Péter Jászi Oszkár és Bibó István téziseit újrafogalmazva egyik 1971es előadásában fejtette ki témánkra vonatkozó nézeteit. Kijelentette, hogy a Monarchia és ezen belül Magyarország felbomlása is egy „hosszú folyamat végeredménye" volt. E folyamat dinamikáját alapvetően az országon belüli és kívüli nacionalizmusok határozták meg, amelyekkel szemben sem az osztrák, sem a magyar kormányok nem tudtak hatékony ellenstratégiát kidolgozni. Pedig a felbomlásnak Hanák szerint is volt alternatívája: ,a demokratikus integráció programja, amelyet a szociáldemokrácia és a polgári radikalizmus képviselt”. Demokratikus reformokkal és különbékével Hanák szerint a folyamat 
talán még a háború első felében is megfordítható lett volna. 1917 végétől, 1918 elejétől azonban már nem. Addigra a legtöbb nemzetiségi csoport vezetésében megerősödött a szeparatizmus, amelyet „,az antant hatalmak befolyásos körei is támogattak". A döntéseket végeredményben tehát a győztes nagyhatalmak hozták, ám a felbomlás ,egy régóta érlelődő történelmi folyamat” végállomása volt (Hanák, 1975, 441-465.).

Az 1980-as években elsősorban olyan munkák születtek, amelyek a trianoni döntés külső okait vizsgálták. Ezek közül kiemelkedik Ormos Máriáé, aki a francia külügyminisztérium addig jórészt ismeretlen iratanyaga alapján nyúlt a témához. Hanákhoz hasonlóan maga is úgy vélte, hogy „A Monarchia két fö, egymást erősítő tényező hatására bomlott fel”: ,a belső feszítő tendenciák tetőzése” és az ezeket támogató „nagyhatalmi törekvések” következtében (Ormos, 1983, 13-14.). Egyik 1985-ös előadásában Kosáry Domokos ugyanebben a szellemben értelmezte a történelmi Magyarország „fölszámolását”. Az „első ok - írta - az volt, hogy az országon belül kiéleződtek a nemzeti ellentétek, a második pedig az, hogy ezeket a nemzeti ellentéteket az első világháború végén felhasználta a győztes hatalmak politikája" (Kosáry, 1989, 15.).

A késői Kádár-korszak történészei tehát két tényezőnek tulajdonítottak meghatározó jelentőséget: a belső nemzetiségi ellentéteknek és a háború alatti és utáni nagyhatalmi politikának. A forradalmi kormányok 1945 előtt hangoztatott felelősségét a rendkívül szűk mozgásterére hivatkozva tagadták vagy minimálisnak tartották, a „reakció", illetve az 1919-20-ban hatalomra került horthysta elit Andics és követői által sulykolt „,hazaárulását” pedig fel sem vetették. A magyarországi történészektől némileg eltérően a Párizsban élő Fejtő Ferenc viszont kizárólag a háborús vereség és a nagyhatalmi érdekek döntő jelentőségét hangsúlyozta franciául 1988-ban, magyarul pedig 1990-ben megjelent könyvében (Fejtő, 1990, 17-27., 323-324., 361.).

Az 1989-90-es rendszerváltást követő években a Trianon iránti érdeklődés megélénkült. A történészek közül ez sokakat indított a kérdéskörrel való valamilyen szintủ szembenézésre. Bár a trianoni békeszerződéssel kutatási szinten nem foglalkozott, annak okairól több alkalommal markáns véleményt nyilvánított Tőkéczki László. Először 1991-ben jelentette ki, hogy 1918-19-ben nem „szétesés, hanem szétverés következett be”. Nem igaz - próbálta indokolni álláspontját -, hogy ,a dualizmus és benne a történelmi Magyarország nem volt képes társadalmi-nemzetiségi problémái megoldására”. A cseh nemzet többsége például „,csak a végső, már eldöntött háborús stádiumban állt a függetlenég mellé”; a „trializmusért hadakozó horvátok” a végsőkig kitartottak; a „mérsékelt szociáldemokrácia pedig nemzeti különbségek nélkül a birodalom, illetve Magyarország mellett állt" - deklarálta bármiféle tényeken alapuló argumentáció nélkül (Tőkéczki, 1999, 78.). A trianoni békeszerződés aláírásának 80. évfordulója alkalmából közzétett publicisztikájában még kategorikusabban fogalmazott. 
„Trianonnak - írta ekkor - nincs mélyen gyökerező elötörténete. [...] Valójában Trianont az első világháború utolsó két évének nagyhatalmi érdekeiből s a korábban adott antantígéretek beváltásából kotyvasztották össze olyan emberek, akik nagy részének fogalma sem volt a térség történelméről és valóságáról.” (Tökéczki, 2000)

1990-ben megjelent dokumentumkötetének (Trianon titkai) bevezetöjében Raffay Ernő sokkal differenciáltabb álláspontot fejtett ki. A trianoni döntés távolabbi okai véleménye szerint három tényezőben keresendők: a „nagyhatalmak, különösen Franciaország magyarellenességében és érdekeiben”, az „,irredenta mozgalmak törekvéseiben” s végül ,a magyar nemzetiségi és külpolitika tévedéseiben". Ezekhez járult a háborúban elszenvedett katonai vereség mint közvetlen ok. Raffay felfogásának a fentieken túl két fontos jellemzője volt. A dualizmus kori magyar nemzetiségpolitika nagy hibájának a tipikus baloldali megközelítésektől eltérően nem a szükkeblüséget, hanem éppen ellenkezőleg, az „engedékenységet”, valamint a népiségtörténet álláspontjához hasonlóan azt tartotta, hogy az „nem párosult a magyar nemzeti érdekek következetes védelmével”, és ugyanakkor „lebecsülte” a nemzetiségi mozgalmakban „rejlő elszakadási törekvések lehetöségének veszélyét". A másik érdekesség: újabb munkáitól eltérően ekkor még elismerően írt Károlyi Mihályról, méltányolva, hogy előbb a diplomácia, majd a „fegyveres honvédelem” eszközeit is bevetve törekedett Magyarország egységének és önállóságának a megőrzésére (Raffay, 1990, 7-9.).

Raffaytól és különösen Tőkéczkitől eltérően, a népiségtörténeti iskola képviselöihez hasonlóan egyik 2005-ös tanulmányában Jeszenszky Géza úgy vélte, hogy a „történelmi Magyar Királyság 1918-21 közötti fölosztásának gyökere” egészen a „mohácsi csatavesztésig” nyúlik vissza. A magyar népesség vérvesztesége, valamint a betelepítések következtében a lakosság etnikai összetétele radikálisan megváltozott. Ez volt a társadalmi alapja a 19. századi nemzetiségi törekvéseknek, amelyek az etnikai alapú területi autonómia követelésében csúcsosodtak ki, s amelytől az ,akkori magyar társadalom elzárkózott”. A magyarok és nem magyarok közötti elmérgesedett viszony okozta, hogy 1918-ra az autonómiatörekvések szeparatizmussá fokozódtak. Hangsúlyozta Jeszenszky a nagyhatalmi érdekérvényesítés fontos szerepét is. Utalt rá, hogy a háború alatti területi ígéretek „már a földarabolás irányába mutattak”, $\mathrm{s}$ arra is, hogy Thomas Woodrow Wilson 1918 elején meghirdetett önrendelkezési programja összecsengett a szeparatista nemzetiségi törekvésekkel. Negyedik tényezőként a Károlyi-kormány naivitását és ebből fakadó tétlenségét említette. Azzal, hogy ,a győztesek ígéreteiben és a majdani békekonferencia méltányosságában bízó Károlyi-kormány nem látta sem értelmét, sem esélyét a fegyveres ellenállásnak, ezért az antant által átadott jegyzékekben kiürítendőnek megjelölt országrészeket harc nélkül föladta”, „sajnos mi magyarok is hozzájárultunk saját balsorsunkhoz" - állapította meg (Jeszenszky, 2005, 7-24.). 
Sajátos, a két világháború közötti jobboldali diskurzus egyes megállapításaira emlékeztető nézeteket fejtett ki egyik 2010-es cikkében Salamon Konrád. A „trianoni békediktátumhoz vezetó útnak" véleménye szerint ugyanis nem a nemzetiségi antagonizmus és nem is a nagyhatalmi akarat, hanem, ,a nemzeti megosztottság, majd az egymással a vörös-, illetve a fehérterror képében polgárháborút vívó két táborra szakadtság volt az egyik legfontosabb meghatározója”. A Trianon felé mutató másik tényezőnek véleménye szerint Magyarország „elkeserítően rossz” nemzetközi megítélése tekinthető az első világháború előtt. Az ország negatív megítélésének okai közt - mint írja - „ott találhatóak a XX. század elején tevékenykedő magyar baloldali ellenzéknek a hazai állapotokat túlzottan elmaradottnak beállító, a kisebbségekkel szembeni magyar elnyomást erősen felnagyító tanulmányai". A fenti tényezőkhöz járultak a két forradalom hibái. Először „Károlyi Mihály elvakult pacifizmusa” és Linder Béla „teljes leszerelést hirdető ostoba katonapolitikája", amelyeket betetőzött a kormány későbbi hadseregszervező munkáját akadályozó „szélsőballal” szembeni erélytelenség, ami végül a kommunisták március 21-i hatalomátvételébe torkollott. Bár a Tanácsköztársaság vállalta a fegyveres harcot a románokkal és a csehekkel szemben, Magyarország képviselői a kommün miatt „,nem jelenhettek meg idejekorán Párizsban, ezért az elkerülhetetlennél is súlyosabb békeszerződéssel sújtották a magyarságot" (Salamon, 2010, 82-85.).

Összegezve a rendszerváltást követően, az elmúlt harminc évben kialakult Trianon-diskurzus magyarázatait, megállapíthatjuk, hogy a magyar történészek többsége - igaz, nem azonos mértékben és változó hangsúlyokkal - négy tényezőnek tulajdonít fontos szerepet. Időrendben haladva ezek a következők: (1) a 19. századi nemzetiségi törekvések és a magyar nemzetiségpolitika; (2) a szomszédos államok és a háború alatti nemzetiségi emigráció irredentizmusa; (3) a győztes nagyhatalmak háború alatti területi ígéretei és vélt vagy valós stratégiai érdekei; (4) a magyarországi belső helyzet. Ettől a többtényezős, komplex magyarázattól ketten térnek el: Tőkéczki László, aki a háború alatti nagyhatalmi politikát és Salamon Konrád, aki a „nemzeti megosztottságot”, a világban kialakult rossz hírünket s különösen a forradalmak politikáját okolja a történtekért.

Trianon okairól persze nemcsak a történészek, hanem a két világháború közötti helyzethez hasonlóan a közélet különböző rendü és rangú emberei is markáns véleményt formálnak. Ezekkel a nem szakmai megközelítésekkel, melyek nagyon gyakran a politikai jobb- és baloldal régi keletủ elöítéletes leegyszerüsítéseit fogalmazzák újra, részletesen nem kívánunk foglalkozni. Trianon-legendák címü tanulmánykötetében Ablonczy Balázs ezt már egyébként is megtette (Ablonczy, 2010). Két jelentős visszhangot kiváltó, ideáltipikus alkotással, melyek sürítetten tartalmazzák a történelmi igazságként prezentált féligazságokat, csúsztatásokat és valótlanságokat, azonban indokolt a szembenézés. E két történelmi példabeszéd szerzői Koltay Gábor filmrendező és Csernok Attila köz- 
gazdász. Deklarált célja mindkét szerzőnek ugyanaz: a trianoni traumával való őszinte szembenézés igénye. A produktum, amit létrehoztak, azonban a lehető legkevésbé sem felel meg ennek a célnak. Tudatosan vagy öntudatlanul mindketten olyan szelektíven kezelték a múlt ismert tényeit, s azokat olyan mértékben ruházták fel ideológiailag meghatározott jelentésekkel, hogy alkotásaik sokkal inkább a történelmi propaganda, semmint a történelmi ismeretterjesztés múfajába tartoznak. Előbbi a két háború közötti jobboldali, utóbbi az akkori baloldali és Andics 1945 utáni propagandisztikus szólamait újította fel (Koltay, 2004; Csernok, 2008, 26-91.).

Az érzelmekre hatni kívánó szubjektivitás, a politikailag motivált egyoldalúság, valamint a bünbakkeresésbe torkolló önsajnálat és az önvád szerencsére nem kizárólagosan uralják a Trianonnal kapcsolatos történelmi ismeretterjesztést. A pozitív ellenpéldák közül kiemelkedik a Szakály István rendezésében készült 2006-os A Trianon szindróma címü film, amelyben a hozzáértő magyar szakértők szinte teljes köre mellett francia, amerikai, cseh, szlovák és román történészek is kifejthették álláspontjukat. A döntés okainak és körülményeinek alapos körüljárásával és multiperspektivikus bemutatásával Szakály és munkatársai - mindenekelőtt a narrátori és moderátori szerepben megjelenő Ablonczy Balázs - hatásosan bizonyították: a legérzékenyebb történelmi témáról is lehet higgadt hangvételü és érvelő jellegü ismeretterjesztő filmet készíteni. Sőt talán azt is, hogy ha valóban szembe akarunk nézni Trianonnal és történelmünk más tragikus eseményeivel, akkor csak így érdemes, és csak így szabad. Az illúzióktól terhes önsajnálattól és a mazochista önostorozástól egyaránt mentes reális önismeret ugyanis nemcsak az egyének, hanem a nemzetek számára is elengedhetetlen.

\section{IRODALOM}

Ablonczy B. (2010): Trianon-legendák. Budapest: Jaffa Kiadó

Andics E. (1949): Nemzetiségi kérdés, nemzetiségi politika. Budapest: Szikra Kiadó

Asztalos M. (1934): A nemzetiségek története Magyarországon - betelepülésüktöl máig. Budapest: Lantos Könyvkiadó

Bibó I. (1981): Összegyüjtött munkái. I. köt. (Sajtó alá rend. Kemény I., Sárközi M.) Bern: EPMSZ Csernok A. (2008): A komáromi pontonhíd. Budapest: Szerző kiadása

Fejtő F. (1990): Requiem egy hajdanvolt birodalomért. Budapest: Atlantisz Kiadó

Hanák P. (1975): Magyarország a Monarchiában. Tanulmányok. Budapest: Gondolat Kiadó Horváth J. (1924): A trianoni béke megalkotása 1915-1920. Budapest: „Magyar Külpolitika”, http://mtdaportal.extra.hu/books/horvath_jeno_a_trianoni_beke_megalkotasa.pdf Jászi O. (1982): A Habsburg-monarchia felbomlása. (ford. Zinner J.) Budapest: Gondolat Kiadó Jeszenszky G. (2005): Trianon, az európai tragédia. Magyar Szemle, XIV, 5-6, http://www.magyarszemle.hu/cikk/20060815_trianon_az_europai_tragedia

Koltay G. (2004): Trianon. Koltay Gábor dokumentumfilmje. Budapest: Korona Film 
Kosáry D. (1989): Nemzeti fejlödés, müvelödés - európai politika. Budapest: MTA Történettudományi Intézet

L. Nagy Zs. (1965): A párizsi békekonferencia és Magyarország 1918-1919. Budapest: Kossuth Könyvkiadó

Németh L. (1989): Sorskérdések. Budapest: Szépirodalmi Kiadó

Ormos M. (1983): Padovától Trianonig 1918-1920. Budapest: Kossuth Könyvkiadó

Raffay E. (1990): Trianon titkai, avagy hogyan bántak el országunkkal... Budapest: Tornado Damenija

Romsics I. (2015): A múlt arcai. Történelem, emlékezet, politika. Budapest: Osiris Kiadó

Salamon K. (2010): Trianon okairól. Trianoni Szemle, II, 1, 82-85.

Szabó I. (1941): A magyarság életrajza. Budapest: Magyar Történelmi Társulat

Szakály I. (2006): A Trianon szindróma. Szakály István dokumentumfilm-sorozata I-V. Budapest: Magyar Televízió-Master Pro Kft.

Tőkéczki L. (1999): Történelem, eszmék, politika. Budapest: Kairosz Kiadó

Tőkéczki L. (2000): Egy nemzetek feletti struktúra szétverése. Magyar Nemzet, június 3. 21. https://magyarnemzet.hu/archivum/archivum-magyarnemzet/egy-nemzetek-feletti-struktura-szetverese-4484879/ 